\title{
University Acceptance Features in the Open Arab University (Jordan Branch) Amman Jordan
}

\author{
Ebtisam. Z. ALmahasneh \\ Ministry of Higher Education and Scientific Research \\ Amman, Jordan \\ Mahmoud. A. ALhabees \\ Associate t Professor \\ Al-Balqa Applied University \\ AL-Salt, Jordan \\ E-mail: alhabeesm@yahoo.com Fax: 0096253491119 Box: 19117(AL-Salt) \\ Accepted: March 23, 2012 \\ Published: May 15, 2012 \\ URL: http://dx.doi.org/10.5430/ijhe.v1n1p168
}

Received: February 11, 2012

doi:10.5430/ijhe.v1n1p168

\begin{abstract}
The objective of this study is to evaluate the experience of the Open Arab University/Jordan branch, in terms of accepted students as well as the graduates from 2002 to 2005, and to conclude on one hand the relation between the students' genders, the majors and the scientific programs, and to study the differences between the number of graduates and some majors and programs.

The study focused only on the Open Arab University/ Jordan branch, by utilizing the official reports published by the university, regarding the general of the number of students accepted in all majors and the number of graduates in these majors.

The study reached a number of important results which are found essential for the decision makers in the higher education department to, as a guide and to show the importance of open education idea towards the open system of education it is a remarkable trial on the level of higher academics and it is the first of its kind in Jordan.
\end{abstract}

Objective: This study sheds light on the Open Arab University/Jordan branch, with special reference to the accepted students as well as the graduates from 2002 to 2005, and to conclude on one hand the relation between the students' genders, majors and scientific programs, and to study the differences between the number of graduates, some majors and programs, and to introduce some recommendations allowing decision makers to upgrade University Acceptance in the Open Arab University/Jordan Branch.

Methods: This study adopted the inductive approach for the special and statistical properties of testing techniques to evaluate University Accepted students and graduates in the Open Arab University/Jordan Branch.

Results: The study is aimed to explore specific statistical relations exist between the gender and academic programs offered by the Open Arab University, the number of graduates and the academic programs. It is clear that the number of students enrolled in the university is increasing and the university introduced new academic programs attractive to students and the labor market. You can see the results by viewing the outcome of the number of students that enrolled in the University. It also shows that all universities in Jordan followed this method.

Keywords: Open Arab University, Acceptance, Features

\section{The background of the study and its importance:}

1) Introduction:

Higher education in Jordan is known for its innovative approach to prepare students to be highly trained, knowledgeable workers well equipped with technical and problem-solving skills. Nowadays, the diffusion of higher education 
institutions, public and private in different parts of the country, reaching number (25) Universities. Ten of these universities governmental (public) universities.

To preserve such distinction, The Ministry of Education and Scientific Research has taken several positive initiatives to encourage universities to use untraditional methods, accordingly. The ministry licensed the Arab Open University to open a branch in Amman, and granted general and special accreditation. The university began accepting students with a capacity of 3000 students, in accordance with General accreditation Council in the Ministry of Higher Education and Scientific Research.

Open University Education is described as generally flexible in its procedures, programmers (Talpin, 2002. Mackenzie\& Scupham, 1975), and techniques as it is characterized to be a non-elitist education, and as educating for life, self dependent, and teaching for a sustainable development in a heterogeneous society. (www.qudsopenu.edu,2006.Botempe,2004.Egan,2001 ), Therefore the Arab Open University was established in 2002 to receive students, males, females regardless of the age or nationality and average in the General Secondary Certificate, regardless of the year of obtaining the certificate. The Open Arab University used the latest version of technology in education and achieved tremendous progress in the means of communication with students and offers the education opportunities for every person in both Jordan and neighboring countries.

The University started to receive students at the beginning of October, 2002, in its branches distributed in Kuwait (the headquarters of the University, Lebanon, Jordan, Saudi Arabia, Bahrain and Egypt by offering different academic topics to study such as; the English Language and Literature, the Program of Information Technology and computing, program of Business studies, three programs for educational studies which are: Bachelor's Degree in Elementary Education, a qualifying Degree in Education, and the Higher Diploma in Education. The accredited hours needed to get the "Bachelor's Degree" for each program ranges between (128-131) hours covering university requirements compulsory and optional and the requirements of specialization. The University has a well organizational structure (the Arab Open University 2006).

This study is attempted to evaluate the open educational experience with a special reference to the Arab Open University, Jordan branch compared with the traditional education system dominated the Higher Education in Jordan.

2) The Study Problem and Questions:

The Higher Education Council at the beginning of each school year specifies conditions to accept students based on the rates of the final high school, among a group of other considerations that will be accepted by the Jordanian universities within the capacity of each University (Badran, 2001, p.282).

The problem of university acceptance is one of the most major problems facing the higher education sector in Jordan, as the failure to resolve the problem would negatively affect the educational process, including academic and administrative problems, financial and technical issues and related labor market and unemployment, and finally the surplus of specialties which are not needed by the labor market.

The branch of the Arab Open University in Amman adopts an educational pattern different from the education systems used in Jordanian universities. The University benefited from the pilot experiences of developed societies in the application of the pattern of open education, to root its role, based on its educational philosophy, and therefore the problem of this study is to evaluate the nature of acceptance of the Open University, and whether it attracted students to study the programs offered by the university.

To highlight the problem of the study, the following questions were drafted:-

1 - What are the standards for admission to the University?

2- Is there a relationship between gender and the specializations?

3 - Does the acceptance to the university differ according to specialization of study?

4- Does the acceptance to the university reveal certain growth rates?

3) The importance of the study:

The study derives its significance from the importance of the application of this new educational system in Jordan, which is regarded as a new experience, counter to the traditional education systems. This type of education is also considered an important one because the educational institutions in Jordan lack the opportunity to grant degrees through Open education, thereby demonstrating the urgent need for, knowing the extent interest of students in it, and the relationship of gender and each subject offered by the university which shows the level of acceptance or rejection of such system by the community (Galusha, 2000). The researcher also aware of what the Ministry of Higher Education 
and Scientific Research is doing now to strengthen this pattern of education. Therefore the present study will have its importance through answering the inquiries of it, and the most important findings and specific recommendations relevant to the nature of this experience, will be suggested to decision makers in higher education in Jordan.

4) Objectives of the Study:

The objectives of the study are specified as follows:

1. Knowing the range of students' interest in such an educational pattern.

2. Revealing the relations between the gender of students and specializations.

3. Revealing the evolution in the acceptance rates and the rates of student growth.

5) The Study Hypotheses:

To achieve the objectives of the study; two hypotheses that were formulated based on the original data obtained from official sources available at the Directorate of Acceptance and Registration in the studied University branch.

The first hypothesis:

There is no statistically significant relationship between gender and specializations.

Second hypothesis:

There are no differences between the numbers of graduates at the level of academic specializations that led to the students 'graduation.

6) Study Curriculum:

To test these hypotheses the study utilized the SPSS package (version 13) for statistical analysis, where:

- $\left(\mathrm{X}^{2}\right)$ test has been applied to test the relationship between the variables studied.

- "Wilcoxon Rank Sum Test" to test the differences between the numbers of graduate students for the years in consideration.

- Student (T) test was done to test the differences between the numbers of graduates in the semesters of the academic year 2004 / 2005.

- Percentages showing ratios development and growth rates of university students.

7) Study Limits:

This present study was limited only to the Arab Open University / Jordan Branch as a case study to identify the developments in accepted students in relation to different academic programs and specialties offered by the university to meet the needs of the labor market and for the period $2002-2005$.

Limitations of the Study:

1- The study restricted to highlight the experience of this branch of the Arab Open University, which does not require dealing with other traditional educational institutions.

2- Researchers depended on the documented and official data being more accurate and realistic compared to what might be obtained through other tools used to collect the data such as interviewing and questionnaires.

3- Internet sites are rich with experiments relevant to the subject of our study, which prompted the researcher for the adoption of a considerable number of previous studies on the subject.

The rest of the paper is organized as follows:

To be tested in this study. The data and variable description are collected from the Open University. While, the findings and the conclusion are discussing in the final study.

\section{Literature review:}

Open education pattern draws a broad interest of those interested in institutions for higher education. This appears clear in conferences symposia and studies held in Jordan and other Arab countries, The Study of Othman ( 1987, p.40) entitled (The Open Education System and the Arab World), diagnosed the reality of higher education in the Arabic countries exemplified in the provision of opportunities for higher education versus the narrow acceptance capacity of the Arab universities. The studies concluded about the most important characteristics of the open education, and clarify the need, to adopt this pattern of education to solve the acceptance problems faced traditional universities, through the establishment of an Arab Open Learning system. Kilani, (1997, p. 106) explained at length the experience of Al-Quds 
Open University, and concluded that the printed educational material is the most important element of this system which is the chief mediator and the effective means to create the bilateral communication between the supervisor and learner.

Hynes and Dillon, (1992, p. 45) illustrated in their study (Distance Learning) the negligible statistical differences in the levels of academic achievement for the university students, who are studying under the open education system and for those students who study according to the traditional educational system. Also they clarify that there is no statistical difference between the interaction of students and attitudes in both the open education system and the traditional one.

Howerton, and others, (1992, p. 41) used a sample of the black students to measure the center of discipline and academic planning in the open education system, and academic achievement. The study reported that students who attributed their success or failure to their abilities and their efforts achieved better in the open education system, compared with their counterparts who attributed the failure or success to external conditions in the traditional education system.

The study of Smith and Mcnelis, (1993, p.71) entitled (the Open Learning) identified the educational trends of students and its relationship with university academic achievement in the Open education system and the traditional education system, through comparing two classes of Higher Studies in both systems. The study concluded negative results in the grades of students in the Open education system compared with those of students in the traditional education system. In a study of ( Hamdan ,2001,P.2841) entitled (Distance Learning), aimed at providing a clear idea about this type of education, and had considered that this pattern is a new pattern of higher education and is similar to the education in traditional universities which has a philosophy, goals and curricula, techniques, professors, organizational structures and special methods of teaching, conducting examinations and granting specific university degree allowing this pattern to be economically effective.

Siam(2003, p. 24) in a study entitled (The Experience of Al-Quds Open University 2003 - 1991), defined this university through its career and the diagnosis of this new experience and what distinguishes it from its counterparts in higher education institutions. The study resulted to the growing numbers of students admitted and the number of graduates from various academic programs at the university which emphasizes the importance of this experience in open education.

Farra, (2003, p. 22) in his study entitled (Distance Learning and Open Education: Roots, Concepts and Justifications), discussed the philosophy of distance learning and open learning, offered several international experiences in countries adopting this pattern of education, and the emergence of the Open Learning. He also gave various definitions Open University education. The study concluded that Open education is capable to meet the social, functional and professional needs through the systems followed and school programs provided and the flexibility in the acceptance and registration, and the capacity to transcend regional, social, and economic borders and access to all categories of the community.

Al-Hnaiti, (2003, p. 30) in a study entitled (Quantity and Quality Standards in Open and Education and Distance Learning), identified the basic elements included in the general accreditation standards- of the university which provides open education programs in Jordan, and explained that the institutions of higher open education subject to the criteria for quality control adopted by the higher education council institutions in Jordan. Also

Abu Ghreeb, (2003, p. 15) provided a study entitled (Pioneer International Experiences in the Field of Open Education and Distance Learning and the Lessons learned), as the Australian, Pakistani, British, Egyptian ones. It highlighted the preliminary activities and the expected results to support the initiative of distance learning in the nine most populous countries: China, India, Indonesia, Pakistan, Bangladesh, Egypt, Nigeria, Brazil, and Mexico, which came in the New Delhi Declaration in 1993.

Hameesh,(2005,p.910) aimed in his study (The Experience of Open Islamic Universities), at reflecting the reality of Islam as a religion and the law of Muslims, especially for Muslims and for mankind as a whole, and the need to revive the Shari'i Science based on the Quran and the Prophet's Sunnah. The study found that the Open Learning accommodate all who wish to study Shari'i Science, and achieve the great purposes of the legitimacy for the characteristics of this kind of education for those who did not have the opportunity to study by other means, which gives the Open Islamic University the opportunity to achieve the objectives and goals expected.

Saa'doun, (2005, p. 931) presented a study entitled :(The Future Outlook For the Open University and Distance Learning in the Arab world).The study aimed at drawing the features of the Open University in Iraq and the Arab world by identifying the basic frameworks in the university to create a system represented by the organizational structure, materials, the study ways, methods and means of education, higher studies, scientific research, finance and acceptance.

The researcher has examined at the legislation of the Ministry of Higher Education and Scientific Research and the decisions made regarding this type of education, along with many relevant studies in a number of websites. One of these studies was the Open Education in Egypt, the United Arab Emirates, Saudi Arabia and the United States of America. (Portal.Ahram.org.ed), the Open Learning Center in computer education (www.opendirectory.sitc.info), the Open 
Learning in Syrian universities (andrecc tripol.Com), the British Arab Academy for Higher Education (www.abahe.co.uk) and the forums of Arab Open University (www.aouform.org).

The international experiences in the field of Open education where also revised, the United Kingdom $(\mathrm{http} / /$ www.yell.com/super.universities/London?sem=g)), The British Open University (http//:www.leapfinder.com/myquery.aspx?query=british\%20open\%20university \& from $=2$ ), the Indian universities that offer Open education (http//:www.education.nic.in/dist_inst.asp), the School of Open education in Germany, which uses The British Open University style (http//: www. Ac.uk/germany), the Open education University in Sri-Lanka (http//:www.ou.ac.IK), the Open University in Finland (http//:www.avoing/iopisto.fi/en-GB), the Open University in Australia (http//:www.open.edu.au/wps/portal) and the Open Education University of Hong Kong (www.ouhk.edu.hk).

\section{Results and discussion:}

Statistical testing of the relationship between gender and specializations according to the year of entry, revealed (table1)

1) Testing the relationship between gender and the specialization of English language and its literatures.

Table (1) shows the existence of statistically significant relationship 5\% of confidence between gender variable and the English language and its literatures specialization with the calculated value of $\left(\mathrm{X}^{2}\right)$ equal to (12.77) and this is larger than its value in the table which is $(7.815)$ at the level of level of $(\alpha=0.05)$ and a statistical sign amounted to $(\mathrm{p}$-value $=$ $0.042<0.05$ ). The results indicate the great interest of Students in this specialization in general, and in favor of females in particular. It is clear from the results that, females' enrollment in English language and literature program is greater than males.

\section{2- Test the relationship between gender and Administrative Systems specialization:}

Table No. (2) Shows the relationship between gender variable and Administrative Systems specialization with the calculated value of $\left(\mathrm{X}^{2}\right)$.

The results of testing the relationship between business studies with system practice table (2) show the existence of statistically significant relationship at the $99 \%$ of confidence $(\alpha=0.01)$ where calculated value of $\left(X^{2}\right)$ equal to $(22.96)$ and this is larger than its value in the value which is (11.345) at the level of the sign $(\alpha=0.01)$ and a statistical sign (p-value $=0.000<0.01)$. The results indicate the great interest of Students in this specialization in general, and in favor of females in particular. It is clear from the results of that, females' enrollment in Administrative Systems is greater than males'.

The results of testing the relationship between gender and Information Technology and computing (table 3) show the existence of statistically significant relationship at the level of sign $(\alpha=0.01)$ between the gender variable and the specialization of Information Technology and Computing. The calculated value of $\left(\mathrm{X}^{2}\right)$ equal to (64. 6) and this is larger than its value in the table which is $(11.345)$ at the level of the $\operatorname{sign}(\alpha=0.01)$ and a statistical sign (p-value $=0.000<$ 0.01). The interpretation between the two variables indicates the great interest of Students in this specialization in general, and in favor of males in particular. It is clear from the results of the table that, males' enrollment in Information Technology and Computation is greater than females.

The results of the relationship in (table 4) between gender and qualifying degree in education show the existence of statistically significant relationship at the level of $\operatorname{sign}(\alpha=0.01)$ between the gender variable and the specialization in the qualifying degree in education. The calculated value of $\left(\mathrm{X}^{2}\right)$ equal to (596.5) and this is larger than its value in the table which is (11.345) at the level of the sign $(\alpha=0.01)$ and a statistical sign (p-value $=0.000<0.01)$. The interpretation of the relationship between the two variables indicates the great interest of Students in this specialization in general, and in favor of females in particular. It is clear from the results of the table that, females' enrollment in the qualifying degree in education is greater than males.

The results of $x^{2}$ testing (table 5) show the existence of statistically significant relationship at the level of sign $(\alpha=0.01)$ between the gender variable and the specialization of elementary education major. The calculated value of $\left(\mathrm{X}^{2}\right)$ is equal to (75.78) and this is larger than the tabulated one (11.345) at the level of the sign $(\alpha=0.01)$ and a statistical sign

(P-value $=0.000<0.01)$. The interpretation of the result of the relationship between the two variables indicates the great interest of Students in this specialization in general, and in favor of females in particular. It is clear from the results of the table that, females' enrollment in elementary education major is greater than males.

The results of $x^{2}$ testing (table 6$)$ show the existence of statistically significant relationship at the level of sign $(\alpha=0.01)$ between the gender variable and the specialization of Higher Diploma in Education. The calculated value of $\left(\mathrm{X}^{2}\right)$ equal to $(65.52)$ which is larger than tabulated one which is $(11.345)$ at the level of the sign $(\alpha=0.01)$ and a statistical sign $(\mathrm{P}$-value $=0.000<0.01)$. The interpretation of the relationship between the two variables indicates the great interest of 
Students in this specialization in general, and in favor of females in particular. It is clear from the results that, females' enrollment in the Higher Diploma in Education is greater than males. The above mentioned $\mathrm{x} 2$ testing results.

The results summarized in (table 7) indicate the verification validity of the first hypothesis, which concludes that "There is a statistically significant relationship between gender variable and the specializations of study.

To test the differences between the numbers of graduates in the specialization of Higher Diploma in Education for the academic years (2003 / 2004) and (2004 / 2005), we decided to test the following statistical hypothesis.

The null hypothesis of (Ho): There are no differences of statistical significant between the numbers of graduates in the specialization of Higher Diploma of Education.

For the verification of acceptance or rejection of the above hypothesis, we decided to use the (Wilcoxon Rank Sum Test), where Table (8) illustrates the results of testing.

The results in table (8) show the existence of statistically significant differences at the level of $(\alpha=0.05)$ between the numbers of graduate in the specialization of Higher Diploma in Education for the three academic semesters in the academic years (2003 / 2004) and (2004 / 2005).

The (Wilcoxon) (U) statistics value (4.5) is less than the minimum critical value (T) of (Wilcoxon) test (5) colony at the level of significance $(=0.05)$. Such results demonstrates the rejection of the null (HO) hypothesis and the acceptance of the alternative hypothesis (which concludes "the existence of differences are statistically significant in numbers of graduates specialization of Higher Diploma in Education at the level of significance $(=0.05)$ for the two years.

It is possible than to verify the validity of the second hypothesis, which states that the existence of "statistically significant differences between the numbers of graduates in the Higher Diploma in Education. Also, a student's (t-test) is applied to test the differences between the numbers of graduates in the specialization of the Qualifying degree in Education, for the academic year (2004 / 2005). The Null hypothesis (Ho) in this regard is there is no difference statistically significant in the numbers of graduates in the Qualifying degree in Education ( $t$ ) Test, Qualifying degree in Education.

It is evident from table (9) the existence of differences statistically significant on the level of $(=0.05)$ between the numbers of graduates in the specialization of the Qualifying degree in Education for three semesters of the academic year (2004 / 2005). The calculated value of $(t)$ amounting to (6.53) and it is larger than the value of tabulated which ( $t)$ is (2.92) at the level of confidence $(\alpha=0.05)$, such results allows to reject the Null hypothesis of (Ho) and the acceptance of the alternative hypothesis $(\mathrm{H})$, which states that "there are differences statistically significant in numbers of graduates in the specialization of the Qualifying degree in Education, at the level of indication $(\alpha=0.05)$ for the mentioned academic year.

On the basis of the previously mentioned results, it is clear from the experience of the Open Learning at the Arab Open University / Jordan Branch, that the numbers of students accepted at the university has increased, and the rates of growth (table 10) for the years (2002 - 2005) was high, which indicated that such experience was successful.

\section{Conclusions:}

The present study enables the researcher to conclude the following:

1) Results showed the validity of the first hypothesis which states "the existence of relationship statistically significant between the gender variable and certain specializations "in general at detailed level, the followings were found:

- Females were highly interested in the specializations of English language and its literature, Elementary Education, Qualifying degree in Education, and the Higher Diploma in Education.

-Males were highly interested in the specializations of Business studies with system practice and Information Technology and Computation.

2) It became clear also the validity of the second hypothesis which states "the existence of differences statistically significant in numbers of graduates on the level of specializations that lead to the graduation of its students" in general, but at the detailed level, the following were found:

- The existence of differences statistically significant in numbers of graduates in the specialization of Higher Diploma in Education at $95 \%$ level of confidence.

- The existence of differences statistically significant in numbers of graduates in the Elementary Education, and in favor of females also at $95 \%$ level of confidence. 
3) The results of the analysis show clear increase of the students' numbers graduated from the university branch, coupled with growth rates in the numbers of students admitted in the academic school years $(2002,2003,2004$, and 2005)

Finally, the researcher suggests several recommendations, which can be summarized as follows:

1) Develop a mechanism for admission to the available programs in the University, and to encourage students to join these academic programs.

2) The need to expand university programs and other disciplines contrast to the traditional disciplines and in line with the needs and requirements of the labor market.

3) The need for the universities of the traditional system to evaluate the experience of the Arab Open University, along with the possibility to apply on-line studies.

4) Conduct further studies on this experience and its role in expanding relatively cheap higher education in Jordan and to reduce the pressure on the present Universities by expanding students' admission through the open system of Education.

\section{References}

Abu Ghareeb, Aida Mayyas. (2003). Test global pioneer in the field of open education and distance learning, lessons learned, the Education and virtual distance education: reality and prospects of the future, University of Philadelphia.

AL-Hnaiti, Abdel-Rahim. (2003). (Quantity and Quality Standards in Open Education and Distance Learning), Virtual Education Conference and Distance Learning: reality and prospects of the future, University of Philadelphia.

Arab Open University/ Jordan Branch (2006) FAQs, Amman, Jordan.

Badran, Adnan. (2001). University Education in Jordan between Reality and Ambition: Future Look, Abdel Hamid Shouman Foundation, Amman.

Bontempe, R. (2004). Motivation and distance learning: What we know so far?Bray, J, (2002) " The Social relationships between learning disable and non-learning disable especial education" Journal Articles, 88(4) 41-48. [Online] Available: www.xplana.com/articles/archive/motv.

Egan, M. (2001). Effective Television Teaching Precipitous of those who count most distance learns". Eric, ED. 342579.

Farra, Ismail Saleh. (2003). Distance Learning and Open Education: Roots, Concepts and Justifications, Virtual Education Conference and Distance Learning: reality and prospects of the future, University of Philadelphia.

Galusha, J. (2000). "Learning in distance education". www3.nesu.edu/dox/nbe/galusha.

Hamdan, Mohammed, (2001), Open Education and Distance Learning, Journal of the Union of Open Arab Universities, No. 39, November, Amman.

Hameesh, Abdel Haq. (2005). Distance Learning: The Experience of open Islamic Universities, Studies and Researches of the Second Arab Education Meeting "Higher Education": Futuristic Visions," the Arab Thought Foundation, $1^{\text {st }}$. edition, Beirut.

Haynes, K, J., \& Dillon, C. (1992). Distance Education: Learning outcomes, interaction, and attitudes, Journal of Education for Library and Information Science. 33 (1). http://dx.doi.org/10.2307/40323480

Howerton, D.L, and others. (1992). Locus of control and achievement of at-risk adolescent black males, ERIC Document: ed. No.354-255.

Kilani, Taiseer. (1997). The Book Role and Educational Techniques in Education, The Experience of Al-quds Open University, Journal of The Union of Open Arab Universities, No. 32, January, Amman.

Mackenzic,N. Postgate,R.\& Scupham,J. (1975). Open Learning: System and Problems in Post, secondary education, Unesco.Paris

Othman, Ali Issa. (1987). Distance learning, a Study of Open Education in the Arab World, the Arab Thought Foundation, ${ }^{\text {st }}$. edition, Beirut.

Saa'doun, Sadoun Hadi. (2005). The Outlook for the Open University and Distance Learning in the Arab world, Studies and Researches of the Second Arab Education Forum "Higher Education": Futuristic Visions," the Arab Thought Foundation, $1^{\text {st }}$. edition, Beirut.

Siam, Ahmad. (2003). The Experience of Al-quds Open University (2003 - 1991) Virtual Education Conference and Distance Learning: reality and prospects of the future, University of Philadelphia 
Smith, D. L \& Mcnelis, M.J. (1993). Distances education: Graduate Student attitudes and academic performances. ER1C Document No. 360-984.

Talpin, M. (2002). the potential of live teacher supported distance learning: A case study, Higher Education, 21(3)258-271.

Websites:

portal.ahram.org.ed

www.opendirectory.sitc.info andreccy tripol.com

www.abahe.co.uk

www.aouform.org

$\mathrm{http} / /$ :www.yell.com/super.uiversities/London?sem=g

$\mathrm{http} / /$ :www.leapfinder.com/myquery.aspx?query=british $20 \%$ open $\% 20$ university \&from=2

http//:www.eduction .inc.in/dist_inst.asp

$\mathrm{http} / /$ :www.open.ac.uk/germay

http//:www.ou.ac.ik

http//:www.avoing/iopisto.fi/en-GB

$\mathrm{http} / /$ :www.open.edu.au/wps/portal

www.ouhj.edu.hk

Table 1. Results of the distinguish between Sex and Major as English Language, using $X^{2}$ Values

\begin{tabular}{|c|c|c|c|c|c|c|c|}
\hline Major & \multicolumn{4}{|c|}{ Language } & \multirow[t]{2}{*}{ Total } & \multirow[t]{2}{*}{$\begin{array}{l}\mathrm{X}^{2} \\
\text { Value }\end{array}$} & \multirow[t]{2}{*}{ Sign. } \\
\hline Sex & 2002 & 2003 & 2004 & 2005 & & & \\
\hline Male & 22 & 10 & 24 & 28 & 84 & 3.20 & \multirow{3}{*}{0.042} \\
\hline Female & 34 & 32 & 26 & 39 & 131 & 9.57 & \\
\hline Total & 56 & 42 & 50 & 67 & 215 & 12.77 & \\
\hline
\end{tabular}

$\mathrm{X}^{2}$ value with (3) degree of freedom with respect to $\alpha \leq 0.05$, is equal to 7.815

Table 2. $\mathrm{x}^{2}$ test between Sex and Business studies with system practice

\begin{tabular}{|c|c|c|c|c|c|c|c|}
\hline Major & & Administrative & \multicolumn{2}{|c|}{ Systems } & \multirow[t]{2}{*}{ Total } & \multirow[t]{2}{*}{$\begin{array}{l}\mathrm{X}^{2} \\
\text { Value }\end{array}$} & \multirow[t]{2}{*}{$\begin{array}{l}\text { Freedom } \\
\text { Sign. }\end{array}$} \\
\hline Sex & 2002 & 2003 & 2004 & 2005 & & & \\
\hline Male & 63 & 37 & 35 & 46 & 181 & 0.49 & \multirow{3}{*}{0.00} \\
\hline Female & 53 & 33 & 35 & 35 & 156 & 22.47 & \\
\hline Total & 226 & 70 & 70 & 81 & 337 & 22.96 & \\
\hline
\end{tabular}

$\mathrm{x}^{2}$ value with (3) degree of freedom with respect to $\alpha \leq 0.01$, is equal to 11.345 
Table 3. Results of the $\mathrm{x}^{2}$ test between Sex and Major as Information Technology and computing

\begin{tabular}{|c|c|c|c|c|c|c|c|}
\hline Major & \multicolumn{2}{|r|}{ Information } & \multicolumn{2}{|c|}{ Technology } & \multirow[t]{2}{*}{ Total } & \multirow[t]{2}{*}{$\begin{array}{l}\mathrm{X}^{2} \\
\text { Value }\end{array}$} & \multirow[t]{2}{*}{$\begin{array}{l}\text { Freedom } \\
\text { Sign. }\end{array}$} \\
\hline Sex & 2002 & 2003 & 2004 & 2005 & & & \\
\hline Male & 102 & 39 & 13 & 23 & 177 & 25.79 & \multirow{3}{*}{0.000} \\
\hline Female & 33 & 26 & 54 & 6 & 119 & 38.82 & \\
\hline Total & 135 & 65 & 67 & 29 & 296 & 64.61 & \\
\hline
\end{tabular}

$\mathrm{x}^{2}$ value with (3) degree of freedom with respect to $\alpha \leq 0.01$, is equal to 11.345

Table 4. Results of $x^{2}$ test between Sex and Major as Supplementary Program, using $X^{2}$ Values

\begin{tabular}{|c|c|c|c|c|c|c|c|}
\hline Major & & Supplementary & \multicolumn{2}{|c|}{ Program } & \multirow[t]{2}{*}{ Total } & \multirow[t]{2}{*}{$\begin{array}{l}\mathrm{X}^{2} \\
\text { Value }\end{array}$} & \multirow[t]{2}{*}{$\begin{array}{l}\text { Freedom } \\
\text { Sign. }\end{array}$} \\
\hline Sex & 2002 & 2003 & 2004 & 2005 & & & \\
\hline Male & 14 & 26 & 179 & 0 & 219 & & \multirow{3}{*}{0.000} \\
\hline Female & 76 & 126 & 22 & 443 & 667 & & \\
\hline Total & 90 & 152 & 201 & 443 & 886 & & \\
\hline
\end{tabular}

Table 5. Results of the $\mathrm{x}^{2}$ test between Sex and elementary education major, using $\mathrm{X}^{2}$ Values

\begin{tabular}{|c|c|c|c|c|c|c|c|}
\hline Major & Education in & Primary & \multicolumn{2}{|c|}{ teaching } & \multirow[t]{2}{*}{ Total } & \multirow[t]{2}{*}{$\begin{array}{l}\mathrm{X}^{2} \\
\text { Value }\end{array}$} & \multirow[t]{2}{*}{$\begin{array}{l}\text { Freedom } \\
\text { Sign. }\end{array}$} \\
\hline Sex & 2002 & 2003 & 2004 & 2005 & & & \\
\hline Male & 5 & 28 & 91 & 32 & 156 & 43.44 & \multirow{3}{*}{0.000} \\
\hline Female & 8 & 51 & 66 & 166 & 291 & 32.34 & \\
\hline Total & 13 & 79 & 157 & 198 & 447 & 75.78 & \\
\hline
\end{tabular}

$\mathrm{x}^{2}$ value with (3) degree of freedom with respect to $\alpha \leq 0.01$, is equal to 11.345

Table 6. Results of the $\mathrm{x}^{2}$ testing between Sex and the Higher Diploma in Education

\begin{tabular}{|c|c|c|c|c|c|c|c|}
\hline Major & Higher & Diploma & \multicolumn{2}{|c|}{ In Education } & \multirow[t]{2}{*}{ Total } & \multirow[t]{2}{*}{$\begin{array}{l}\mathrm{X}^{2} \\
\text { Value }\end{array}$} & \multirow[t]{2}{*}{$\begin{array}{l}\text { Freedom } \\
\text { Sign. }\end{array}$} \\
\hline Sex & 2002 & 2003 & 2004 & 2005 & & & \\
\hline Male & 13 & 4 & 18 & 2 & 37 & 53.67 & \multirow{3}{*}{0.000} \\
\hline Female & 17 & 29 & 14 & 108 & 168 & 11.85 & \\
\hline Total & 30 & 33 & 32 & 110 & 205 & 65.52 & \\
\hline
\end{tabular}

$\mathrm{x}^{2}$ value with (3) degree of freedom with respect to $\alpha \leq 0.01$, is equal to 11.345 
Table 7. Results of the relation between Sex and the studied Majors

\begin{tabular}{|l|l|l|l|}
\hline Variable & Majors & $\mathrm{X}^{2}$ Value & P-Value \\
\hline \multirow{5}{*}{ Gender } & English Languageand Literature & 12.77 & 0.042 \\
\cline { 2 - 4 } & Business studies with system practice & 22.96 & 0.000 \\
\cline { 2 - 4 } & Information Technology and Computing & 64.61 & 0.000 \\
\cline { 2 - 4 } & & & \\
\cline { 2 - 4 } & Qualifying degree in Education & 596.50 & 0.000 \\
\cline { 2 - 4 } & Elementary Education & 75.78 & 0.000 \\
\cline { 2 - 4 } & Higher Diploma in Education & 65.52 & 0.000 \\
\hline
\end{tabular}

Table 8. results of testing the differences between the numbers of graduates in the Higher Diploma of Education using (Wilcoxon) test

\begin{tabular}{|c|c|c|c|c|c|c|}
\hline \multirow{2}{*}{ Year of graduation } & \multirow{2}{*}{$\begin{array}{l}2003 \\
/ 2004\end{array}$} & \multirow{2}{*}{$\begin{array}{l}2004 \\
/ 2005\end{array}$} & \multirow[t]{2}{*}{$\begin{array}{l}\text { Wilcoxon } \\
\text { Value } \\
\mathrm{U}=\min \left(\mathrm{u}_{1}, \mathrm{u}_{2}\right)\end{array}$} & \multicolumn{2}{|c|}{$\begin{array}{l}\text { Critical value } \\
\text { Wilcoxon }\end{array}$} & \multirow[t]{2}{*}{ Dicison } \\
\hline & & & & TU & TL & \\
\hline First & 49 & 32 & \multirow{3}{*}{4.5} & \multirow{3}{*}{16} & \multirow{3}{*}{5} & \multirow{3}{*}{$\begin{array}{l}\text { Reject } \\
\text { Hypothe-sis } \\
\left(\mathrm{H}_{0)}\right.\end{array}$} \\
\hline Second & 20 & 26 & & & & \\
\hline Summer & 32 & 38 & & & & \\
\hline
\end{tabular}

Table 9. Results of differences between numbers of graduates in qualifying degree in Education using ( $t$ ) test

\begin{tabular}{|l|l|l|l|l|}
\hline Semesters & $\begin{array}{l}\text { No. of graduates } \\
2004 / 2005\end{array}$ & Value of $(\mathrm{t})$ calculated & Significant value & Decision \\
\hline First & 105 & \multirow{2}{*}{6.53} & \multirow{2}{*}{0.036} & $\begin{array}{l}\text { Reject the } \\
\text { hypothesis } \\
\mathrm{H}_{0}\end{array}$ \\
\hline Second & 170 & & & \\
\hline Summer & 178 &
\end{tabular}

The value of $(t)=2.92$ using degree of freedom of 2 and $\alpha \leq 0.05$

Table 10. the development of the students' number admitted during the academic years (2002 - 2005)

\begin{tabular}{|l|l|l|l|l|}
\hline Year & $\begin{array}{l}\text { Number of } \\
\text { Accepted Students }\end{array}$ & Percentage & $\begin{array}{l}\text { Percentage } \\
\text { development }\end{array}$ & $\begin{array}{l}\text { Percentage of } \\
\text { growth }\end{array}$ \\
\hline 2002 & 440 & $18.4 \%$ & -- & -- \\
\hline 2003 & 441 & $18.5 \%$ & $0.1 \%$ & $0.1 \%$ \\
\hline 2004 & 577 & $24.2 \%$ & $5.7 \%$ & $5.6 \%$ \\
\hline 2005 & 928 & $38.9 \%$ & $14.7 \%$ & $9.0 \%$ \\
\hline Total & 2386 & $100 \%$ & -- & -- \\
\hline
\end{tabular}

